\title{
Effects of silicate application on soil fertility and wheat yield ${ }^{1}$
}

\author{
Efeitos da aplicação de silicato na fertilidade do solo e rendimento \\ do trigo
}

\author{
Marcos Vinícius Mansano Sarto ${ }^{2 *}$; Maria do Carmo Lana ${ }^{3}$, Leandro Rampim; \\ Jean Sérgio Rosset ${ }^{5}$ Jaqueline Rocha Wobeto ${ }^{6}$
}

\begin{abstract}
An improvement in soil chemical properties and crop development with silicate application has been confirmed in several plant species. The effects of silicate application on soil chemical properties and wheat growth were investigated in the present study. The experiment was carried out in 8-L plastic pots in a greenhouse. Treatments were arranged in a randomized block design in a $3 \times 5$ factorial: three soils [Rhodic Acrudox (Ox1), Rhodic Hapludox (Ox2) and Arenic Hapludult (Ult)] and five silicate rates (0, 1, 2, 4 and $6 \mathrm{Mg} \mathrm{ha}^{-1}$ of calcium/magnesium silicate), with four replications. The plant length, number of spikes per pot, shoot dry matter and grain yield, were measured after 115 days of wheat (Triticum aestivum L.) growth. Changes in the soil chemical properties $\left(\mathrm{pH}, \mathrm{H}^{+}+\mathrm{Al}^{3+}, \mathrm{Al}^{3+}, \mathrm{P}, \mathrm{K}, \mathrm{Ca}, \mathrm{Mg}, \mathrm{Si}\right.$, $\mathrm{Cu}, \mathrm{Zn}, \mathrm{Fe}$ and $\mathrm{Mn}$ ) were analyzed after wheat harvest. Application of calcium/magnesium silicate reduces the potential acidity $\left(\mathrm{H}^{+}+\mathrm{Al}^{3+}\right)$ and $\mathrm{Al}^{3+}$ phytotoxic; and increases the soil $\mathrm{pH}$, available $\mathrm{Ca}$, $\mathrm{Mg}$ and Si, cation exchange capacity (CEC) and soil base saturation. Silicate application did not affect the available $\mathrm{P}$, exchangeable $\mathrm{K}$ and availability of micronutrients $(\mathrm{Cu}, \mathrm{Zn}, \mathrm{Fe}$ and $\mathrm{Mn})$ in the three soils. The application of calcium/magnesium silicate in an acid clayey Rhodic Hapludox improves the development and yield of wheat; however, the silicate application in soil with $\mathrm{pH}$ higher to 5.3 and high $\mathrm{Si}$ availability does not affect the agronomic characteristics and grain yield of wheat.
\end{abstract}

Key words: Triticum aestivum L., silicon, chemical properties, acidity correction source

\section{Resumo}

Melhorias das propriedades químicas do solo e do desenvolvimento das culturas com aplicação de silicato foi confirmado em várias espécies de plantas. Os efeitos da aplicação de silicato nas propriedades químicas do solo e crescimento do trigo foram investigados no presente estudo. O experimento foi realizado em vasos plásticos de $8 \mathrm{~L}$ em estufa. Os tratamentos foram dispostos em um delineamento em blocos casualizados, em esquema fatorial $3 \times 5$ : três solos [Latossolo Vermelho eutroférrico (LVef), Latossolo Vermelho distroférrico (LVd) e Argissolo Vermelho-Amarelo eutrófico (PVAe)] e cinco doses

\footnotetext{
${ }^{1}$ Parte da dissertação de mestrado do primeiro autor, Universidade Estadual do Oeste do Paraná, UNIOESTE, Marechal Cândido Rondon, PR, Brasil.

2 Discente do Curso de Doutorado do Programa de Pós Graduação em Agronomia -Agricultura, Universidade Estadual Paulista, UNESP, Faculdade de Ciências Agronômicas, FCA, Botucatu, SP, Brasil. E-mail: marcos_sarto@hotmail.com

${ }^{3}$ Prof ${ }^{a}$ Associada do Centro de Ciências Agrárias, CCA, UNIOESTE, Bolsista CNPq, Marechal Cândido Rondon, PR, Brasil. E-mail: maria.lana@unioeste.br

${ }^{4}$ Prof. Adjunto, Universidade Estadual do Centro-Oeste - UNICENTRO, Guarapuava, PR, Brasil. E-mail: rampimleandro@ yahoo.com.br

5 Prof. Adjunto IV - Universidade Estadual de Mato Grosso do Sul - UEMS - Mundo Novo, MS, Brasil. E-mail: rosset@uems.br

${ }^{6}$ Discente do Curso de Doutorado do Programa de Pós Graduação em Zootecnia, Faculdade de Medicina Veterinária e Zootecnia, UNESP, Botucatu, SP, Brasil. E-mail: jaque_wobeto@hotmail.com

* Author for correspondence
} 
de silicato ( $0,1,2,4$ e $6 \mathrm{Mg}$ ha $^{-1}$ de silicato de cálcio / magnésio), com quatro repetições. O comprimento da planta, número de espigas por vaso, matéria seca e rendimento de grãos, foram medidos após 115 dias de crescimento do trigo (Triticum aestivum L.). As alterações nas propriedades químicas do solo $\left(\mathrm{pH}, \mathrm{H}^{+}+\mathrm{Al}^{3+}, \mathrm{Al}^{3+}, \mathrm{P}, \mathrm{K}, \mathrm{Ca}, \mathrm{Mg}, \mathrm{Si}, \mathrm{Cu}, \mathrm{Zn}, \mathrm{Fe}\right.$ e $\mathrm{Mn}$ ) foram analisados após a colheita. A aplicação de silicato de cálcio/magnésio reduz a acidez potencial $\left(\mathrm{H}^{+}+\mathrm{Al}^{3+}\right)$ e $\mathrm{Al}^{3+}$ fitotóxico; e aumenta o $\mathrm{pH}$ do solo, $\mathrm{Ca}, \mathrm{Mg}$ e Si disponível, capacidade de troca catiônica (CTC) e saturação por bases. Aplicação de silicato não afetou o $\mathrm{P}$ disponível, $\mathrm{K}$ trocável e disponibilidade de micronutrientes $(\mathrm{Cu}, \mathrm{Zn}, \mathrm{Fe}$ e $\mathrm{Mn})$ nos três solos. A aplicação de silicato de cálcio/magnésio em um Latossolo Vermelho argiloso ácido melhora o desenvolvimento e a produtividade do trigo; no entanto, a aplicação de silicato em solos com $\mathrm{pH}$ superior a 5,3 e alta disponibilidade Si não afeta as características agronômicas e produtividade de grãos do trigo.

Palavras-chave: Triticum aestivum L., silício, propriedades químicas, correção da acidez

\section{Introduction}

Soil acidity limits the crop production in considerable areas of the world. Calcium (Ca) deficiency and toxicity caused by aluminum (Al) and manganese $(\mathrm{Mn})$ are the factors that most have limited the productivity of acid soils in tropical and subtropical regions. The problems of soil acidity are normally corrected through the use of limestone or silicate. Fageria and Zimmermann (1998) reported that the ideal $\mathrm{pH}$ for soybean, common bean, maize and wheat growth is around 6.0, which emphasizes the importance of correcting acid soils for appropriate crop development.

Limestone is the most applied source for acidity correction in Brazil due to its price and capacity to increase fertilizer efficiency. Nevertheless, limestone is not a very soluble material and its dissociated components show limited mobility, usually restricting correction effects in uppermost soil layers, mainly under non-mobilized conditions of no-till (CASTRO; CRUSCIOL, 2013; SORATTO; CRUSCIOL, 2008). However, other materials may be applied for acidity correction, as long as the product is constituted by neutralizing components such as calcium and/or magnesium oxides, hydroxides, carbonates and silicates. Calcium and magnesium silicates are similar to carbonates in composition; so, those sources can potentially replace lime even more advantageously (CASTRO; CRUSCIOL, 2013; CAMARGO et al., 2007; CARVALHO-PUPATTO et al., 2004). Thus, studies have shown that the calcium/magnesium silicates can be used as corrective of soil acidity and as silicon ( $\mathrm{Si}$ ) source (CASTRO; CRUSCIOL, 2013; CRUSCIOL et al., 2009; PULZ et al., 2008; CARVALHO-PUPATTO et al., 2004), in addition to increasing $\mathrm{Ca}, \mathrm{Mg}$, CEC values and base saturation soil (SARTO et al., 2014a). Recommendation for silicate application can be based on any methods of limestone requirement (KORNDÖRFER et al., 1999b). Compared to limestone, there are fewer studies on silicate application as an acidity correction source for crop yield in agricultural production systems. Field research on the application of calcium/magnesium silicate indicate this source can be more efficient than other materials (limestone, aqueous lime and sewage sludge) for correction of deeper soil layers due to their higher solubility (CASTRO; CRUSCIOL, 2013; CORRÊA et al., 2007).

Beneficial effects of silicate application on the crop development and yield has been confirmed in several crops such as rice (CARVALHOPUPATTO et al., 2004), sugar cane (REIS et al., 2013), maize (CASTRO; CRUSCIOL, 2013) and wheat (PROVANCE-BOWLEY et al., 2010), which are considered Si-accumulating species. Silicate benefits may be related to silicon (Si) effects on plants under biotic or abiotic stress conditions even though it is not considered an essential element for plant growth, either physiologically or metabolically (EPSTEIN; BLOOM, 2005). The largest growth and grain yield of plants grown with 
the Si supply is associated to the changes in plant architectures, making them more erect, improving the leaves angle and light interception, avoiding the excessive self-shading, delaying senescence, increasing the structural rigidity of the tissues and improving photosynthesis and reducing lodging (GONG; CHEN, 2012; MA; YAMAJI, 2008). These beneficial effects are attributed to $\mathrm{Si}$ deposited in the cell wall of various plant organs (MA; YAMAJI, 2006) and by other mechanisms. High deposition of $\mathrm{Si}$ in tissues forms a physical barrier that enhances the strength and rigidity of the tissues.

Considering that the use of silicate tends to be most common agricultural practice in Brazil, an improved understanding of the effects of silicate on soil properties and wheat crop development is essential in order to adopt management strategies for improving crop production. In this context, the purpose of this study was to investigate the effects of silicate application soil chemical properties and wheat (Triticum aestivum L.) yield in the three soils of the western region of Paraná - Brazil.

\section{Material and Methods}

Pot experiments were carried out in a greenhouse in Marechal Cândido Rondon, Paraná State, Brazil ( $24^{\circ} 31^{\prime} \mathrm{S}, 54^{\circ} 01^{\prime} \mathrm{W}$, and $420 \mathrm{~m}$ a.s.1.), where the environmental conditions were: minimum and maximum mean air temperature of 18 and $36{ }^{\circ} \mathrm{C}$, respectively; mean air relative humidity of $65 \%$.

Surface samples $(0.0-0.20 \mathrm{~m})$ from three representative soils of the western region of Paraná
State were selected for silicon fertilization studies (Table 1). The physical and chemical properties of the soils were determined by adopting standard procedures, and some properties are shown in Table 2. Soil $\mathrm{pH}$ in $0.01 \mathrm{~mol} \mathrm{~L}^{-1} \mathrm{CaCl}_{2}$ solution was determined potentiometrically in a 1:2.5 (soil:solution) suspension using a combined calomel reference glass electrode and $\mathrm{pH}$ meter. Organic matter was quantified by oxidation with potassium dichromate in the presence of sulfuric acid, followed by titration with ammonium Fe (II) sulfate (EMBRAPA, 2009). Available phosphorus $(\mathrm{P})$, exchangeable potassium $(\mathrm{K})$ and cationic micronutrients $(\mathrm{Cu}, \mathrm{Zn}, \mathrm{Fe}$ and $\mathrm{Mn})$ were extracted by Mehlich-1 solution in a 1:10 (w:v) soil-toextractant solution ratio (EMBRAPA, 2009) and $\mathrm{P}$ was determined by colorimetry at $725 \mathrm{~nm}$ wave length and $\mathrm{K}$ and micronutrients were determined by atomic absorption spectrophotometry. Calcium (Ca) and magnesium $(\mathrm{Mg})$ were extracted by 1 mol $\mathrm{L}^{-1} \mathrm{KCl}$ solution and determined by atomic absorption spectrophotometry (EMBRAPA, 2009). Cation exchange capacity (CEC) was estimated by the summation method $(\mathrm{CEC}=\mathrm{H}+\mathrm{Al}+\mathrm{Ca}+\mathrm{Mg}$ $+\mathrm{K})$. Soluble silicon was extracted by $0.5 \mathrm{~mol} \mathrm{~L}^{-1}$ acetic acid solution in a 1:10 (w:v) soil-to-extractant solution ratio (KORNDÖRFER et al., 1999a) and determined by beta molybdosilicic complex formation, using a spectrophotometer at $660 \mathrm{~nm}$ wave length. Particle size analysis was performed by the pipette method (EMBRAPA, 1997), based on decantation speed of different soil particles after dispersion in $0.015 \mathrm{~mol} \mathrm{~L}^{-1}\left(\mathrm{NaPO}_{3}\right)_{6} \cdot \mathrm{NaO} / 1.0 \mathrm{~mol}$ $\mathrm{L}^{-1} \mathrm{NaOH}$ by overnight shaking.

Table 1. Brazilian soil classification, approximate equivalence to soil taxonomy and sampling site of the three soils from Paraná State.

\begin{tabular}{cccc}
\hline Soil & Brazilian soil classification $^{\dagger}$ & Soil taxonomy $^{\dagger \dagger}$ & Sampling Municipality \\
\hline Ox1 & Eutroferric Red Latosol & Rhodic Acrudox & Marechal Cândido Rondon \\
Ox2 & Distroferric Red Latosol & Rhodic Hapludox & Cascavel \\
Ult & Red-Yellow Argisol & Arenic Hapludult & Goioerê \\
\hline
\end{tabular}

${ }^{\dagger}$ According to EMBRAPA (2013). ${ }^{\dagger}$ USDA Soil Taxonomy (SOIL SURVEY STAFF, 2010). 
The experimental design was a $3 \times 5$ factorial in complete randomized blocks, with four replications. Treatments consisted of three soils [Rhodic Acrudox (Ox1), Rhodic Hapludox (Ox2) and Arenic Hapludult (Ult)] and growing wheat plants with 0 (control), 1, 2, 4 and $6 \mathrm{Mg} \mathrm{ha}^{-1}$ of calcium/magnesium silicate. The silicate source used was AgroSilício ${ }^{\circledR}$ (Si 10.5\%; Ca 25\%, Mg 6\% and ECCE 88\%). The corrected soils were kept for 15 days with water content at $60 \%$ field capacity. Then the soils were placed in 8-L plastic pots and fertilized with applying $30 \mathrm{mg} \mathrm{kg}^{-1}$ of $\mathrm{N}$ (urea), 60 $\mathrm{mg} \mathrm{kg}-1$ of $\mathrm{P}$ (simple superphosphate) and $45 \mathrm{mg}$ $\mathrm{kg}^{-1}$ of $\mathrm{K}$ (potassium chloride). At 30 days after plant emergence, the application of $45 \mathrm{mg} \mathrm{kg}^{-1} \mathrm{~N}$ as urea a solution was also performed.

Table 2. Some physical and chemical properties of the soils.

\begin{tabular}{lccc}
\hline \multirow{2}{*}{ Soil characteristics } & \multicolumn{3}{c}{ Soil } \\
\cline { 2 - 4 } & Acrudox & Hapludox & Hapludult \\
\hline Soil pH & 5.3 & 4.1 & 6.2 \\
Clay $\left(\mathrm{g} \mathrm{kg}^{-1}\right)$ & 550.0 & 535.0 & 100.0 \\
Silt $\left(\mathrm{g} \mathrm{kg}^{-1}\right)$ & 370.0 & 430.0 & 45.0 \\
Sand $\left(\mathrm{g} \mathrm{kg}^{-1}\right)$ & 80.0 & 35.0 & 855.0 \\
Organic matter $\left(\mathrm{g} \mathrm{kg}^{-1}\right)$ & 26.0 & 39.6 & 22.0 \\
Available P $\left(\mathrm{mg} \mathrm{kg}^{-1}\right)$ & 37.1 & 22.5 & 40.7 \\
$\mathrm{H}+\mathrm{Al}\left(\mathrm{cmol}_{\mathrm{c}} \mathrm{kg}^{-1}\right)$ & 4.6 & 10.7 & 2.0 \\
Exchangeable Al $\left(\mathrm{cmol}_{\mathrm{c}} \mathrm{kg}^{-1}\right)$ & 0.0 & 2.4 & 0.0 \\
Exchangeable K $\left(\mathrm{cmol}_{\mathrm{c}} \mathrm{kg}^{-1}\right)$ & 0.15 & 0.20 & 0.20 \\
Calcium $\left(\mathrm{cmol}_{\mathrm{c}} \mathrm{kg}^{-1}\right)$ & 4.8 & 4.0 & 2.5 \\
Magnesium $\left(\mathrm{cmol}_{\mathrm{c}} \mathrm{kg}^{-1}\right)$ & 1.8 & 0.5 & 0.7 \\
$\mathrm{CEC}\left(\mathrm{cmol}_{\mathrm{c}} \mathrm{kg}^{-1}\right)^{\dagger}$ & 11.4 & 15.4 & 5.4 \\
Soil base saturation $(\%)$ & 60.0 & 30.0 & 63.0 \\
Copper $\left(\mathrm{mg} \mathrm{kg}^{-1}\right)$ & 15.0 & 8.2 & 9.9 \\
Zinc $\left(\mathrm{mg} \mathrm{kg}^{-1}\right)$ & 132.0 & 110.0 & 247.0 \\
Iron $\left(\mathrm{mg} \mathrm{kg}^{-1}\right)$ & 41.1 & 35.4 & 28.5 \\
Manganese $\left(\mathrm{mg} \mathrm{kg}^{-1}\right)$ & 3.9 & 8.2 & 5.4 \\
Silicon $\left(\mathrm{mg} \mathrm{kg}^{-1}\right)$ & 19.3 & 15.8 & 18.0 \\
\hline
\end{tabular}

$\uparrow$ CEC: cation exchange capacity.

Five seeds of wheat (Triticum aestivum L., cv. BRS Pardela) were sown, and nine days after seedling emergence, they were thinned to three plants per pot. The pots were irrigated daily for maintain soil moisture near at the field capacity.

At maturity (115 days after plant emergence), the crop yield was evaluated in terms of shoot dry matter production (SDM, g pot ${ }^{-1}$ ) and grain yield $\left(\mathrm{g} \mathrm{pot}^{-1}\right)$. Plants of all treatments were harvested separately, dried for four days at $60 \pm 2{ }^{\circ} \mathrm{C}$, and then weighed. The shoot length was measured $(\mathrm{cm}$ plant $^{-1}$ ) using meter scale. The number of spikes per pot was also measured.

After wheat harvest, soil samples were collected for evaluation of changes in the soil chemical properties ( $\mathrm{pH}, \mathrm{H}+\mathrm{Al}, \mathrm{P}, \mathrm{K}, \mathrm{Ca}, \mathrm{Mg}, \mathrm{Al}^{3+}, \mathrm{Si}, \mathrm{Cu}$, $\mathrm{Zn}, \mathrm{Fe}$ and $\mathrm{Mn}$ ). Soil samples were oven-dried at 50 ${ }^{\circ} \mathrm{C}$ for $48 \mathrm{~h}$, ground to pass through a $2 \mathrm{~mm}$ mesh screen and analyzed as previously described by EMBRAPA (2009) and Korndörfer et al. (1999a).

Original data were analyzed by ANOVA and regression analysis, and significant equations with 
the highest coefficients of determination (F test, $P$ $\leq 0.05$ ) were adjusted. All analyses were performed using Saeg 8.0 software for Windows (Statistical Analysis Software, UFV, Viçosa, MG, BRA).

\section{Results and Discussion}

The results of the soil chemical analyses showed that there was significant interaction between soil type and calcium/magnesium silicate rates (Figure 1).

Application of calcium/magnesium silicate increased the $\mathrm{pH}$ of the three soils (Figure 1A). Studies show that silicate materials have great potential to improve soil chemical characteristics, mainly by increasing the $\mathrm{pH}$ (SARTO et al., 2014b; CASTRO; CRUSCIOL, 2013; CORRÊA et al., 2007; CAMARGO et al., 2007; CARVALHOPUPATTO et al., 2004), confirming that the calcium/ magnesium silicate can be used as corrective of soil acidity. As silicate dissolves in the soil, calcium (Ca) moves to the surface of soil particles, replacing the acidity $\left(\mathrm{H}^{+}\right)$. The acidity reacts with the silicate $\left(\mathrm{SiO}_{3}{ }^{2-}\right)$ to form orthosilicic acid $\left(\mathrm{H}_{4} \mathrm{SiO}_{4}\right)$ and water $\left(\mathrm{H}_{2} \mathrm{O}\right)$ (ALCARDE; RODELLA, 2003). The result is a soil that is less acidic (has a higher $\mathrm{pH}$ ). Calcium and magnesium silicate can be source for soil acidity correction more efficient than other materials such as limestone and sewage sludge. Corrêa et al. (2007) found that $\mathrm{pH}$ was increased by silicate application down to $0.40 \mathrm{~m}$ after 15 months, whereas liming effects were confined down to $0.10 \mathrm{~m}$, on profile of a dystrophic Rhodic Hapludox, medium texture. Evaluate the superficial application of limestone and calcium/magnesium silicate in a deep acid clayey Rhodic Hapludox, Castro and Crusciol (2013) verified that, after 12 months from their application, liming effects had only influenced $\mathrm{pH}$ down to $0.05 \mathrm{~m}$, while silicate increased $\mathrm{pH}$ at $0.10-0.20 \mathrm{~m}$ depth. Compared to lime, silicate is more efficient in correcting acidity down the profile due to its higher solubility (ALCARDE; RODELLA, 2003). As silicate reaction is faster in uppermost soil layers, an alkalinization front is formed to correct acidity of deeper layers in a shorter period of time (CASTRO; CRUSCIOL, 2013).

Calcium and magnesium silicate reduced the potential acidity $\left(\mathrm{H}^{+}+\mathrm{Al}^{3+}\right)$ levels of $\mathrm{Ox} 1$ and $\mathrm{Ox} 2$ soils (Figure 1B). The decrease of $\mathrm{H}^{+}$and $\mathrm{Al}^{3+}$ values occurs by increasing the hydroxyl $\left(\mathrm{OH}^{-}\right)$ concentration in the soil, resulting from silicate application, in which a fraction of these $\mathrm{OH}^{-}$reacts with the excess of $\mathrm{H}^{+}$in solution, increasing the soil $\mathrm{pH}$, and the remainder of these promotes aluminum precipitation in $\mathrm{Al}(\mathrm{OH})_{3}$, which on is non-toxic to plants (STEINER et al., 2012). Application of up to $6 \mathrm{Mg} \mathrm{ha}^{-1}$ of silicate did not change the soil potential acidity of Ult (Figure 1B), due to high initial $\mathrm{pH}$ value (6.2) and low $\mathrm{H}^{+}$and $\mathrm{Al}^{3+}$ levels $\left(2.0 \mathrm{cmol}_{\mathrm{c}}\right.$ $\mathrm{kg}^{-1}$ ) compared with the other soils (Table 2).

Silicate reduced the $\mathrm{Al}^{3+}$ phytotoxic levels of $\mathrm{Ox} 2$ soil (Figure 1C). Exchangeable $\mathrm{Al}^{3+}$ levels can be both decreased by increasing $\mathrm{pH}$ (CARVALHOPUPATTO et al., 2004) or by reactions with $\mathrm{Si}$ and later precipitation as hydroxoaluminosilicate, which reduces its availability (HODSON; SANGSTER, 1999). Castro and Crusciol (2013) found that silicate is more efficient than limestone to reducing toxic aluminum in soil profile, due to their greater solubility (CORRÊA et al., 2007). $\mathrm{SiO}_{3}{ }^{2-}$ is the neutralizing agent in silicates, which reacts with water releasing $\mathrm{OH}^{-}$ions that neutralize $\mathrm{H}^{+}$and $\mathrm{Al}^{3+}$ phytotoxic, consequently increasing $\mathrm{Ca}, \mathrm{Mg}$ and base saturation (ALCARDE; RODELLA, 2003). For the Ox1 and Ult, $\mathrm{Al}^{3+}$ levels were low or zero due to the high $\mathrm{pH}$ values and were not affected by the silicate application (Figure 1C). The soil $\mathrm{pH}$ is probably the single most important management factor controlling the amount of $\mathrm{Al}^{3+}$ phytotoxic in the soil solution. Exchangeable $\mathrm{Al}$ is present in the soil when the $\mathrm{pH}$ begins to drop below $\mathrm{pH}$ 5.5. Even then, it is rarely a problem until the soil $\mathrm{pH}$ drops below $\mathrm{pH}$ 5.0. However, the amount of $\mathrm{Al}^{3+}$ phytotoxic increases dramatically in the majority of soils as the soil $\mathrm{pH}$ drops below pH 5.0 (MOTTA; MELO, 2009), reporting the importance of soil acidity correction to reduce the soil Al level. 
Figure 1. Effects of silicate application in three soils of the western region of Paraná State on the $\mathrm{pH}(\mathrm{A}), \mathrm{H}+\mathrm{Al}(\mathrm{B})$, exchangeable $\mathrm{Al}(\mathrm{C}), \mathrm{Ca}(\mathrm{D}), \mathrm{Mg}(\mathrm{E}), \mathrm{CEC}(\mathrm{F})$, base saturation $(\mathrm{G})$ and $\mathrm{Si}(\mathrm{H})$ after wheat harvest. ns: not significant. $*$ and **: statistical significance at $5 \%$ and $1 \%$, respectively, by $\mathrm{F}$ test.
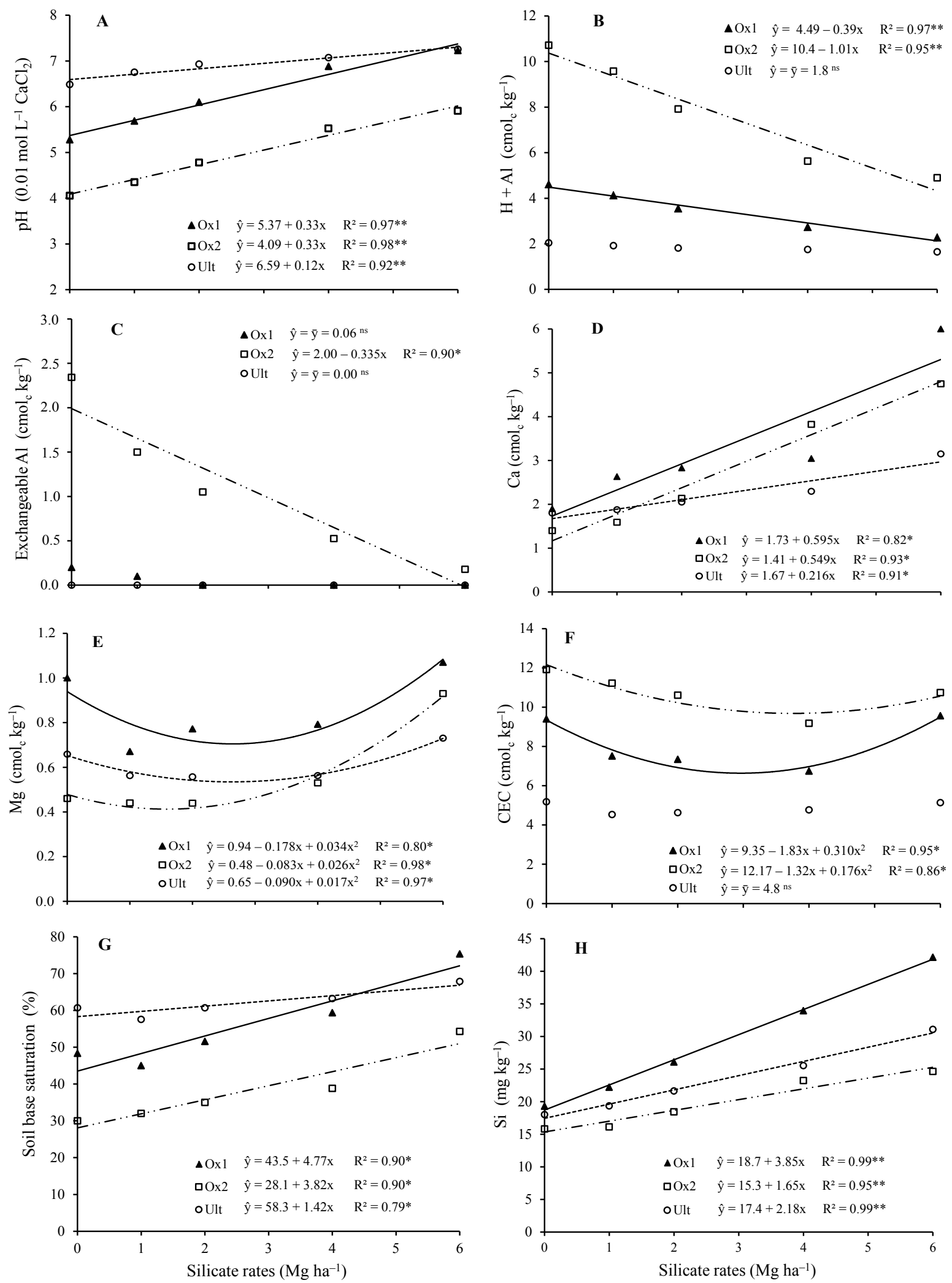
Silicate application increased $\mathrm{Ca}$ levels in the three soils (Figure 1D). The application of $6 \mathrm{Mg}$ $\mathrm{ha}^{-1}$ calcium/magnesium silicate increased the $\mathrm{Ca}$ levels in the Ox1, Ox2 and Ult soils in 206\%, 234\% and $78 \%$, respectively, compared to the control treatment. The results presented here are similar to those reported by Castro and Crusciol (2013), who found increases on Ca levels in the soil after the silicate application. This increase in $\mathrm{Ca}$ level in the soils is due to supply of this nutrient with calcium/ magnesium silicate rates.

Magnesium levels were affected by soil correction with silicate in the three soils (Figure 1E). The minimum $\mathrm{Mg}$ level in the Ox1, Ox2 and Ult were $0.71,0.41$ and $0.55 \mathrm{cmol}_{\mathrm{c}} \mathrm{kg}^{-1}$ obtained with the application of 2.62, 1.60 and $2.65 \mathrm{Mg} \mathrm{ha}^{-1}$ of calcium/magnesium silicate, respectively.

The soil correction with calcium/magnesium silicate affected the cation exchange capacity (CEC) of Ox1 and Ox2, and did not alter the CEC of Ult (Figure 1F). The minimum CEC value in the Ox1 and $\mathrm{Ox} 2$ was 6.65 and $9.70 \mathrm{cmol}_{\mathrm{c}} \mathrm{kg}^{-1}$ obtained with the application of 2.95 and $3.75 \mathrm{Mg} \mathrm{ha}^{-1}$ of silicate, respectively. The Ox2 has the highest CEC values compared to the other soils (Figure 1F), but it also has the highest potential acidity levels (Figure 1B), indicating that a significant portion of the soil negative charges are occupied by $\mathrm{H}^{+}$and $\mathrm{Al}^{3+}$ ions. On the other hand, the fact of soil correction with silicate have not affected the CEC of the Ult can be explained by the high initial $\mathrm{pH}$ value and low buffering capacity of this soil due to its sandy texture (Table 2). In addition, the correction effect decreases when the $\mathrm{pH}$ reaches high values (ASSIS et al., 2007).

Effects of soil correction on $\mathrm{H}^{+}+\mathrm{Al}^{3+}, \mathrm{Ca}$ and $\mathrm{Mg}$ levels reflected in changes on soil base saturation in the three soils (Figure 1G). The application of $6 \mathrm{Mg} \mathrm{ha}^{-1}$ silicate increased the base saturation in the Ox1, Ox 2 and Ult in $66 \%, 81 \%$ and $15 \%$, respectively, compared to the control treatment. The increase in the base saturation values is related to increase of soil $\mathrm{pH}$ and increase the $\mathrm{Ca}$ and $\mathrm{Mg}$ levels, confirming the results reported by Korndörfer et al. (2010) and Sarto et al. (2014b). Regarding the Ox2 soil, the low percentage of base saturation indicates that a significant portion of the exchange sites being occupied by $\mathrm{H}^{+}$and $\mathrm{Al}^{3+}$ ions (Figure 1B). Prates et al. (2011) found that the CEC and base saturation were higher with the application of calcium/magnesium silicate in relation to the Ca supply contained in this corrective. The use of calcium/magnesium silicate can be applied as soil corrective, with the advantage of also supply Si to the plants, which makes crops less susceptible to environmental stress (GUNES et al., 2008).

Silicate application increased available Si levels of the three soils (Figure 1H). Application of 6 $\mathrm{Mg} \mathrm{ha}^{-1}$ silicate increased the available Si levels in the Ox1, Ox2 and Ult in $124 \%, 65 \%$ and $75 \%$, respectively, compared to the control treatment. The increasing of Si availability in the soil with silicate application is normally reported in other studies (SARTO et al., 2014b; CASTRO; CRUSCIOL, 2013; CORREAA et al., 2007). This result may be attributed to the supply of this element with the silicate and solubilization of silica compounds as $\mathrm{pH}$ increases or reduced capacity of $\mathrm{Si}$ bonds to colloid sorption sites, increasing its concentration in soil solution, as reported by Pulz et al. (2008). The increases in availability of $\mathrm{Ca}, \mathrm{Mg}$ and $\mathrm{Si}$ with application of calcium/magnesium silicate were expected because this source has high solubility in the soil (CASTRO; CRUSCIOL, 2013) and possess in their chemical composition $10.5 \%$ of $\mathrm{Si}, 25 \%$ of $\mathrm{Ca}$ and $6 \%$ of Mg. According to Alcarde and Rodella (2003), silicate is 6.78 times more soluble than limestone. The results presented here are similar to those reported by Castro and Crusciol (2013), Korndörfer et al. (2010), Corrêa et al. (2007).

Application of calcium/magnesium silicate did not affect the available $\mathrm{P}$, exchangeable $\mathrm{K}$ and availability of micronutrients in the three soils (Table 3). On the other hand, Castro and Crusciol (2013) 
found that the silicate application, in soil with low $\mathrm{P}$, was capable of increasing $\mathrm{P}$ availability. According to these authors, these results are attributed to the competition between Si and P for the same sorption sites of soil colloids, increasing $\mathrm{P}$ availability to plants. However, in this study the silicate application does not affected the soil $\mathrm{P}$ availability, probably due to high initial concentration of $\mathrm{P}$ in the soils studied.

Table 3. Available $\mathrm{P}$, exchangeable $\mathrm{K}$, and availability of micronutrients ( $\mathrm{Cu}, \mathrm{Zn}, \mathrm{Fe}$ and $\mathrm{Mn})$ after wheat harvest as affected by silicate application in three soils of the western region of Paraná State.

\begin{tabular}{|c|c|c|c|c|c|c|c|c|c|}
\hline \multirow{2}{*}{$\begin{array}{c}\text { Silicate } \\
\text { rates }\end{array}$} & \multicolumn{3}{|c|}{ Available P } & \multicolumn{3}{|c|}{ Exchangeable K } & \multicolumn{3}{|c|}{ Available $\mathrm{Cu}$} \\
\hline & Acrudox & Hapludox & Hapludult & Acrudox & Hapludox & Hapludult & Acrudox & Hapludox & Hapludult \\
\hline $\mathrm{Mg} \mathrm{ha}^{-1}$ & \multicolumn{3}{|c|}{$\mathrm{mg} \mathrm{kg}^{-1}$} & \multicolumn{3}{|c|}{$\mathrm{cmol}_{\mathrm{c}} \mathrm{kg}^{-1}$} & \multicolumn{3}{|c|}{$\mathrm{mg} \mathrm{kg}^{-1}$} \\
\hline 0 & 37.7 & 55.0 & 49.4 & 0.13 & 0.19 & 0.20 & 16.7 & 6.6 & 4.6 \\
\hline 1 & 66.3 & 48.3 & 42.6 & 0.15 & 0.15 & 0.16 & 15.8 & 6.0 & 6.5 \\
\hline 2 & 35.3 & 37.7 & 53.9 & 0.19 & 0.15 & 0.16 & 16.6 & 5.9 & 7.0 \\
\hline 4 & 41.5 & 23.3 & 52.8 & 0.17 & 0.16 & 0.17 & 16.9 & 5.6 & 5.7 \\
\hline 6 & 48.7 & 36.2 & 77.7 & 0.19 & 0.15 & 0.20 & 17.0 & 5.7 & 5.9 \\
\hline Mean & 45.9 & 40.1 & 55.3 & 0.17 & 0.16 & 0.18 & 16.6 & 6.0 & 5.9 \\
\hline Teste F & & $0.63^{\mathrm{ns}}$ & & & $0.56^{\mathrm{ns}}$ & & & $0.38^{\mathrm{ns}}$ & \\
\hline CV $(\%)$ & & 53.0 & & & 21.6 & & & 12.4 & \\
\hline \multirow{2}{*}{$\begin{array}{c}\text { Silicate } \\
\text { rates }\end{array}$} & \multicolumn{3}{|c|}{ Available Zn } & \multicolumn{3}{|c|}{ Available Fe } & \multicolumn{3}{|c|}{ Available Mn } \\
\hline & Acrudox & Hapludox & Hapludult & Acrudox & Hapludox & Hapludult & Acrudox & Hapludox & Hapludult \\
\hline $\mathrm{Mg} \mathrm{ha}^{-1}$ & \multicolumn{3}{|c|}{$\mathrm{mg} \mathrm{kg}^{-1}$} & \multicolumn{3}{|c|}{$\mathrm{mg} \mathrm{kg}^{-1}$} & \multicolumn{3}{|c|}{$\mathrm{mg} \mathrm{kg}^{-1}$} \\
\hline 0 & 14.2 & 10.7 & 18.2 & 46.0 & 38.2 & 24.1 & 7.8 & 8.5 & 15.3 \\
\hline 1 & 20.9 & 11.2 & 7.4 & 48.4 & 39.8 & 32.2 & 20.9 & 16.8 & 7.0 \\
\hline 2 & 11.2 & 7.0 & 14.2 & 55.6 & 41.6 & 28.2 & 11.2 & 9.0 & 14.4 \\
\hline 4 & 13.8 & 17.3 & 5.7 & 60.8 & 40.1 & 28.0 & 13.8 & 18.3 & 9.5 \\
\hline 6 & 14.8 & 29.2 & 17.5 & 55.9 & 41.7 & 41.6 & 14.8 & 26.1 & 14.5 \\
\hline Mean & 15.0 & 15.1 & 12.6 & 53.4 & 40.3 & 30.8 & 13.7 & 15.7 & 12.1 \\
\hline Teste F & & $0.88^{\mathrm{ns}}$ & & & $0.93^{\mathrm{ns}}$ & & & $1.20^{\mathrm{ns}}$ & \\
\hline CV (\%) & & 68.7 & & & 14.9 & & & 62.5 & \\
\hline
\end{tabular}

ns: not significant by $\mathrm{F}$ test. $\mathrm{CV}$ : coefficient of variation.

The increase of soil $\mathrm{pH}$ caused by increased rates of soil acidity correction reduces the availability of cationic micronutrients, such as $\mathrm{Cu}, \mathrm{Zn}, \mathrm{Fe}$ and Mn (PEGORARO et al., 2006). However, in this study the silicate application does not alter the availability of soil micronutrients. According to Prado et al. (2004), the controversial effects of silicate application on micronutrients availability in the soil can be attributed to variations resulting from the parent material and the process used by the steel industry, which influences the chemical composition of the acidity corrective.
Application of calcium/magnesium silicate improved the wheat development in the Ox2 soil (Figure 2), as can be seen by the increase in the plant height, shoot dry matter, number of spikes per pot and grain yield of wheat with increasing rates of calcium/magnesium silicate. The maximum plant height and shoot dry matter was $90.4 \mathrm{~cm}$ (Figures 2A) and $61.1 \mathrm{~g} /$ pot (Figures 2B), respectively, both obtained with the application of $4.2 \mathrm{Mg} \mathrm{ha}^{-1}$ of silicate. The percentage of increase in the number of spikes per pot and grain yield of wheat was $120 \%$ and $42 \%$, respectively, when comparing the 
growing wheat plants with 0 (control) and $6 \mathrm{Mg}$ $\mathrm{ha}^{-1}$ of silicate (Figures 2C and 2D). The increase in the wheat development and yield was due to improve of soil chemical properties (Figure 1). This soil was initially acid and had low amounts of basic cations (Table 2). Aluminum $\left(\mathrm{Al}^{3+}\right)$ toxicity and $\mathrm{Ca}$ deficiency are considered the main factors limiting plant growth in acid soils, mainly by inhibiting root growth (STEINER et al., 2012). The damage to the root system results in exploration of a smaller volume of soil by the plants and losses in nutrient uptake and utilization of soil water and consequently the productive potential of plants (CHAFFAI et al., 2005).

Figure 2. Effects of silicate application in three soils of the western region of Paraná State on the plant height (A), shoot dry matter (B), number of spikes per pot (C) and grain yield (D). ns: not significant. * and **: statistical significance at $5 \%$ and $1 \%$, respectively, by $\mathrm{F}$ test.
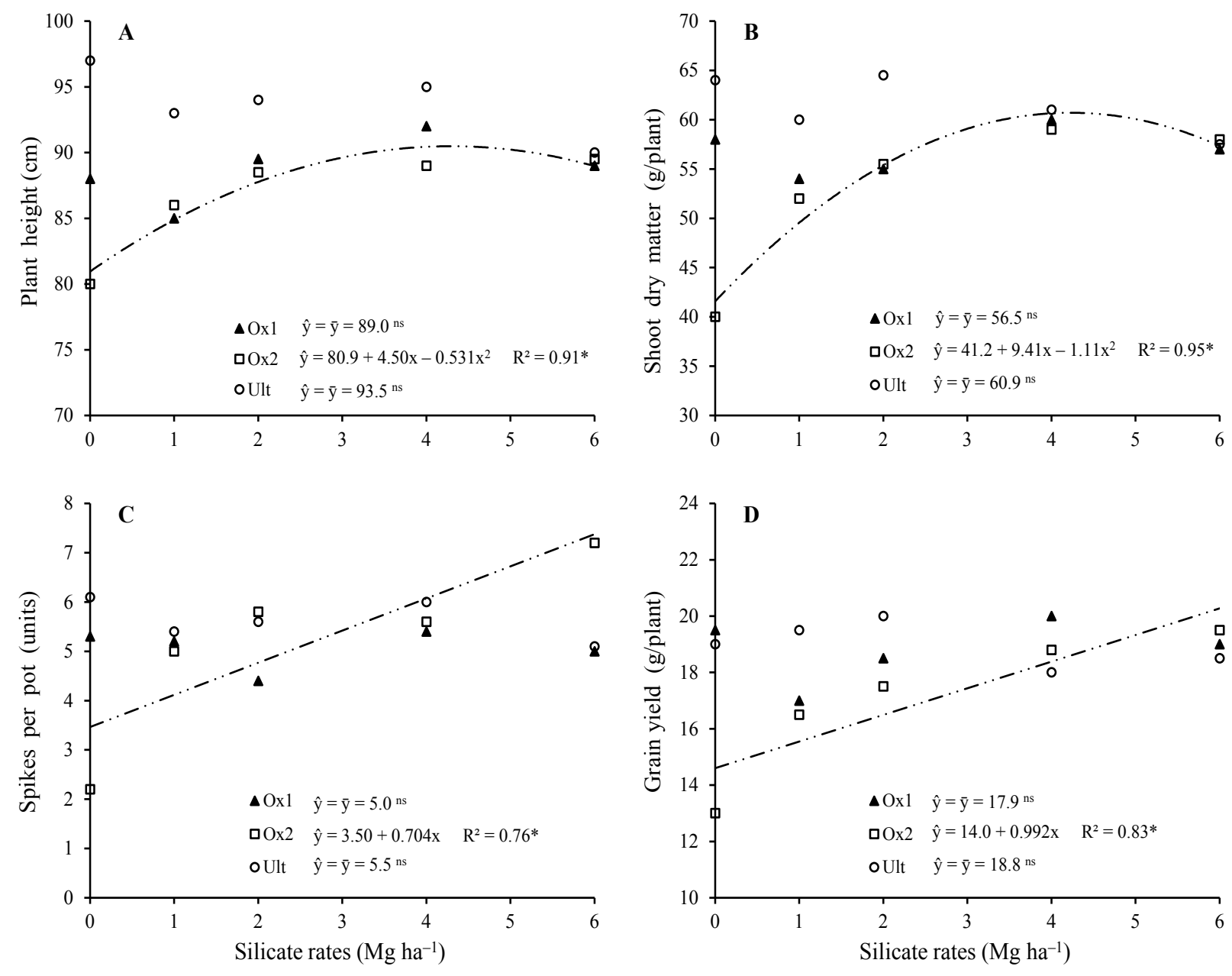

Beneficial effects of silicate application on wheat development and yield was expected as reported by Provance-Bowley et al. (2010), who found a $10 \%$ increase of wheat yield with silicate application. Silicate benefits in increased wheat yield is related

to improvement in soil properties and the Si effects on plant growth. Silicon positively influences plant growth and grain yield, especially monocotyledons, as a consequence of improved structural rigidity of the tissues, better angle of leaves and light 
interception, improving photosynthetic rate (GONG; CHEN, 2012; MA; YAMAJI, 2008). According to Elawad et al. (1982) Si is involved in cell elongation and division processes as well as in hormone balance.

Silicate application did not affect plant height, shoot dry matter, number of spikes per pot and grain yield of wheat in the Ox1 and Ult soils (Figure 2). The results presented here are similar to those reported by Korndörfer et al. (2010) and Tokura et al. (2007); these authors found that the silicate application did no effect dry matter yield of Brachiaria grasses and rice, respectively. We can identify two basic factors for justify this lack of response to application of calcium/magnesium silicate: the first factor, is associated with high initial $\mathrm{pH}$ value of these soils (i.e., initial pH of 5.3 in the Ox1 and 6.2 in the Ult, Table 2). According to Fageria and Zimmermann (1998), the ideal soil $\mathrm{pH}$ for wheat growth is around 6.0. Therefore, the use of soil acidity corrective had little effect on improving of soil properties for growing wheat. The second factor related to the lack of response to silicate application is due to the high Si level in these soils at the beginning of the experiment (Table 2). According to Korndörfer et al. (1999b), when the levels of soil available $\mathrm{Si}$ extracted by $0.5 \mathrm{~mol} \mathrm{~L}^{-1}$ acetic acid solution, are greater than $10.0 \mathrm{mg} \mathrm{kg}^{-1}$ increased grain yield of grass species to the Si supply is unlikely. These values correspond to the critical Si level in the soil and are sufficient to achieve $90 \%$ of maximum grain yield. In general, the beneficial effects of silicate application are reported under biotic or abiotic stress conditions.

\section{Conclusions}

Application of calcium/magnesium silicate reduces the potential acidity $\left(\mathrm{H}^{+}+\mathrm{Al}^{3+}\right)$ and $\mathrm{Al}^{3+}$ phytotoxic; and increases the soil $\mathrm{pH}$, availability of $\mathrm{Ca}, \mathrm{Mg}$ and $\mathrm{Si}$, cation exchange capacity (CEC) and soil base saturation.
Silicate application did not alter the availability of $\mathrm{P}, \mathrm{K}$ and cationic micronutrients in the soils.

The application of calcium/magnesium silicate in an acid clayey Rhodic Hapludox improves the development and yield of wheat; however, the silicate application in soils with $\mathrm{pH}$ higher to 5.3 and high $\mathrm{Si}$ availability does not affect the agronomic characteristics and grain yield of wheat.

\section{Acknowledgments}

To CAPES (Coordination for the Improvement of Higher Education Personnel), for financial support and providing scholarship to the first author.

To CNPq (National Council for Scientific and Technological Development), for an award for excellence in research to the second author.

\section{References}

ALCARDE, J. A.; RODELLA, A. A. Quality and legislations of fertilizer and acidity correction sources. In: CURI, N.; MARQUES, J. J.; GUILHERME, L. R. G.; LIMA, J. M.; LOPES, A. S.; ALVARES V.; V. H. (Ed.). Topics in soil science. Viçosa: SBCS, 2003. p. 291-334.

ASSIS, M. H. S.; PEREIRA, H. S.; BARBOSA, N. C.; CARNEIRO, M. A. C.; PAIVA, J. B. Formas de aplicação de fertilizante silicatado e seus efeitos no solo e na produção de sorgo. In: CONGRESSO BRASILEIRO DE CIÊNCIA DO SOLO, 31., 2007, Gramado. Anais... Gramado: SBCS, 2007. CD-ROM.

CAMARGO, M. S.; PEREIRA, H. S.; KORNDÖRFER, G. H.; QUEIROZ, A. A.; REIS, C. B. Soil reaction and absorption of silicon by rice. Scientia Agricola, Piracicaba, v. 64, n. 2, p. 176-180, 2007.

CARVALHO-PUPATTO, J. G.; BÜLL, L. T.; CRUSCIOL, C. A. C. Atributos químicos do solo, crescimento radicular e produtividade do arroz de acordo com a aplicação de escórias. Pesquisa Agropecuária Brasileira, Brasília, v. 39, n. 12, p. 1213-1218, 2004.

CASTRO, G. S. A.; CRUSCIOL, C. A. C. Effects of superficial liming and silicate application on soil fertility and crop yield under rotation. Geoderma, Amsterdam, v. 195-196, p. 234-242, 2013. 
CHAFFAI, R. R.; MARZOUK, B.; FERJANI, E. E. Aluminum mediates compositional alterations of polar lipid classes in maize seedlings. Phytochemistry, Cambridge, v. 66, n. 16, p. 1903-1912, 2005.

CORRÊA, J. C.; BÜLL, L. T.; CRUSCIOL, C. A. C.; MARCELINO, R.; MAUAD, M. Liming and ion mobility in an Oxisol under surface application of flue dust, aqueous lime, sewage sludge and limestone. Pesquisa Agropecuária Brasileira, Brasília, v. 42, n. 9, p. 1307-1317, 2007.

CRUSCIOL, C. A. C.; PULZ, A. L.; LEMOS, L. B.; SORATTO, R. P.; LIMA, G. P. P. Effects of silicon and drought stress on tuber yield and leaf biochemical characteristics in potato. Crop Science, Madison, v. 49, n. 3, p. 949-954, 2009.

ELAWAD, S. H.; STREET, J. J.; GASCHO, G. J. Response of sugarcane to silicate source and rate. I. Growth and yield. Agronomy Journal, Madison, v. 74, n. 3, p. 481-484, 1982.

EMPRESA BRASILEIRA DE PESQUISA AGROPECUÁRIA - EMBRAPA. Manual de métodos de análise de solo. Rio de Janeiro: Embrapa Solos, 1997. 212 p.

Manual de análises químicas de solos, plantas e fertilizantes. 2. ed. Brasília: Informação Tecnológica, 2009. 628 p.

. Sistema brasileiro de classificação de solos. 3 . ed. Rio de Janeiro: Embrapa Solos, 2013. 353 p.

EPSTEIN, E.; BLOOM, A. J. Mineral Nutrition of plants: principles and perspectives. Sunderland: Sinauer Associates, 2005. 400 p.

FAGERIA, N. K.; ZIMMERMANN, F. J. P. Influence of $\mathrm{pH}$ on growth and nutrient uptake by crop species in an Oxisol. Communications in Soil Science and Plant Analysis, Athens, v. 29, n. 17-18, p. 2675-2682, 1998.

GONG, H.; CHEN, K. The regulatory role of silicon on water relations, photosynthetic gas exchange, and carboxylation activities of wheat leaves in field drought conditions. Acta Physiology Plant, Cracóvia, v. 34, n. 4, p. 1-6, 2012.

GUNES, A.; PILBEAM, D. J.; INAL, A.; COBAN, S. Influence of silicon on sunflower cultivars under drought stress, I: growth, antioxidant mechanisms, and lipid peroxidation. Communications in Soil Science and Plant Analysis, Athens, v. 39, n. 13-14, p. 1885-1903, 2008.

HODSON, M. J.; SANGSTER, A. G. Aluminium/ silicon interactions in conifers. Journal of Inorganic Biochemistry, Columbia, v. 76, n. 2, p. 89-98, 1999.
KORNDÖRFER, G. H.; ARANTES, V. A.; CORRÊA, G. F.; SNYDER, G. H. Efeito do silicato de cálcio no teor de silício no solo e na produção de grãos de arroz de sequeiro. Revista Brasileira de Ciência do Solo, Viçosa, MG, v. 23, n. 3, p. 635-641, 1999b.

KORNDÖRFER, G. H.; COELHO, N. M.; SNYDER, G. H.; MIZUTANI, C. T. Avaliação de métodos de extração de silício em solos cultivados com arroz de sequeiro. Revista Brasileira de Ciência do Solo, Viçosa, MG, v. 23, n. 1, p. 101-106, 1999a.

KORNDÖRFER, P. H.; SILVA, G. C.; TEIXEIRA, I. R.; SILVA, A. G.; FREITAS, R. S. Efeito da adubação silicatada sobre gramíneas forrageiras e características químicas do solo. Pesquisa Agropecuária Tropical, Goiânia, v. 40, n. 2, p. 119-125, 2010.

MA, J. F.; YAMAJI, N. Functions and transport of silicon in plants. Cellular and Molecular Life Sciences, Switzerland, v. 65, n. 19, p. 3049-3057, 2008.

Silicon uptake and accumulation in higher plants. Trends Plant Science, Cambridge, v. 11, n. 8, p. 342-397, 2006.

MOTTA, A. C. V.; MELO, V. F. Química dos solos ácidos. In: ALLEONI, L. R. F.; MELO, V. F. Química e mineralogia do solo. Viçosa: SBCS, 2009. cap. 17, p. 133-380.

PEGORARO, R. F; SILVA, I. R.; NOVAIS, R. F.; MENDONÇA, E. S.; GEBRIM, F. O.; MOREIRA, F. F. Fluxo difusivo e biodisponibilidade de zinco, cobre, ferro e manganês no solo: influência da calagem, textura do solo e resíduos vegetais. Revista Brasileira de Ciência do Solo, Viçosa, MG, v. 30, n. 5, p. 859-868, 2006.

PRADO, R. M.; NATALE, W.; FERNANDES, F. M. Liberação de micronutrientes de uma escória de siderurgia aplicada em um Latossolo Vermelho Amarelo. Revista de Agricultura, Piracicaba, v. 79, p. 260-274, 2004.

PRATES, F. B. S.; SAMPAIO, R. A.; SILVA, W. J.; FERNANDES, L. A.; ZUBA JUNIOR, G. R.; SATURNINO, H. M. Crescimento e teores de macronutrientes em pinhão manso adubado com lodo de esgoto e silicato de cálcio e magnésio. Revista Caatinga, Mossoró, v. 4, n. 2, p. 101-112, 2011.

PROVANCE-BOWLEY, M. C.; HECKMAN, J. R.; DURNER, E. F. Calcium silicate suppresses powdery mildew and increases yield of field grown wheat. Soil Science Society of America Journal, Madison, v. 74, n. 5, p. 1652-1661, 2010.

PUlZ, A. L.; CRUSCIOL, C. A. C.; LEMOS, L. B.; SORATTO, R. P. Influência de silicato e calcário na nutrição, produtividade e qualidade da batata sob 
deficiência hídrica. Revista Brasileira de Ciência do Solo, Viçosa, MG, v. 32, n. 4, p. 1651-1659, 2008.

REIS, J. J. D.; ALOVISI, A. M. T.; FERREIRA, J. A. A.; ALOVISI, A. A.; GOMES, C. F. Atributos químicos do solo e produção da cana-de-açúcar em resposta ao silicato de cálcio. Revista de Ciências Agrárias, Lisboa, v. 36, n. 1, p. 3-9, 2013.

SARTO, M.V.M.; LANA, M.C.; RAMPIM, L.; ROSSET, J. S.; WOBETO, J. R.; ECCO, M.; BASSEGIO, D.; COSTA, P. F. Effect of silicate on nutrition and yield of wheat. African Journal of Agricultural Research, Lagos, v. 9, n. 11, p. 956-962, 2014 b.

SARTO, M.; RAMPIM, L.; LANA, M.; ROSSET, J.; ECCO, M.; WOBETO, J. Atributos químicos do solo e desenvolvimento da cultura do trigo em função da adubação silicatada. Agrarian, Dourados, v. 7, n. 25, p. 390-400, 2014a.
SOIL SURVEY STAFF. Keys to soil taxonomy. $10^{\text {th }}$ ed. Washington, DC: USDA-Natural Resources Conservation Service, 2010.

SORATTO, R. P.; CRUSCIOL, C. A. C. Nutrição e produtividade de grãos da aveia-preta em função da aplicação de calcário e gesso em superfície na implantação do sistema plantio direto. Revista Brasileira de Ciência do Solo, Viçosa, MG, v. 32, n. 2, p. 715-725, 2008.

STEINER, F.; ZOZ, T.; PINTO JUNIOR, A. S.; CASTAGNARA, D. D.; DRANSKI, J. A. L. Effects of aluminum on plant growth and nutrient uptake in young physic nut plants. Semina: Ciências Agrárias, Londrina, v. 33, n. 5, p. 1779-1788, 2012.

TOKURA, A. M.; FURTINI NETO, A. E.; CURI, N.; CARNEIRO, L. F.; ALOVIS, A. A. Silício e fósforo em diferentes solos cultivados com arroz de sequeiro. Acta Scientiarum. Agronomy, Maringá, v. 29, n. 1, p. 9-16, 2007. 